Family Medicine and Community Health

\section{Journey of a Lifetime}

To cite: Rucker TW. Journey of a Lifetime. Fam Med Com Health 2019;7. doi:10.1136/fmch2018-000083

Received 10 December 2018 Accepted 10 December 2018

Check for updates

(c) Author(s) (or their employer(s)) 2019. Re-use permitted under CC BY-NC. No commercial re-use. See rights and permissions. Published by BMJ.

University of Virginia School of Medicine, Nellysford, Viginia, USA

Correspondence to Dr Tinsley White Rucker; twruckermd@aol.com
As I work with medical students and family medicine residents at the University of Virginia (UVA) School of Medicine, I remind them that they are where I was four decades ago, and I am where they will be in four decades. Our combined careers, which will probably exceed eight decades, will see many technical changes, but the essentials of family medicine will remain much as they were in the days of Hippocrates. An experienced clinician has always been one who listens to the patient, understands what is being said, analyses all available data and, together with the patient, designs a plan for diagnosis and treatment. The next generation of clinicians should also understand that it is still possible in an era of government regulation and corporate intervention for an individual clinician to make a significant difference for both patients and the community. While best practices and evidence-based medicine are important, it is equally important to be innovative, finding new and better ways to help patients. The key is to understand the communities in which patients live.

My contemporaries and I led practices for many years, developing unique skills that could be useful to the next generation of family physicians. Even if employed and not in private practice, new physicians need to know how the healthcare system functions and what they can do to make the system more responsive to the needs of patients. There will always be a significant need for physicians to assume leadership positions within healthcare.

My experience with family medicine began in 1970, when I was a US Army infantry lieutenant leading a reconnaissance platoon in Vietnam. The platoon averaged 20 members, and missions consisted of 10-14 day patrols in rural mountainous areas. Two of the most important members of the platoon were the medics. What was accomplished by these medics was extraordinary. They insured everyone took their malaria medications, instructed us on ways to reduce malaria exposure, made certain the drinking water was safe, provided routine medical care and stabilised the wounded. When we approached a village, they would care for the local inhabitants. All this was done with what they carried on their backs in their medic's bag. This low-tech, high-touch care was extremely effective. After their Vietnam experience, many army medics went on to become the first physician assistants. After my Vietnam experience, I was chosen by the army to attend medical school before returning to active duty.

As a freshman medical student at Emory University School of Medicine in 1972, I spent every Thursday in a community medicine course that exposed me to epidemiology, public health and the social determinants of healthcare. Epidemiologists from the Centers for Disease Control spoke about the recently conducted smallpox eradication programmes. Medical students were encouraged to participate in indigent clinics throughout Atlanta. Several of us worked at a clinic in Plunkett Town, a low-wealth community in an old part of Atlanta, where we came to understand their unique struggles. One woman in the community showed an interest in the medical student volunteers by coming to each clinic, introducing us to community members and having us attend church with her. My classmates and I also came to know Dr Alan Blum, a medical student with a passion for changing the tobacco culture. After medical school, he founded Doctors Ought to Care, a national non-profit organisation that creates pioneering strategies to counteract tobacco use and promotion.

When considering various specialties for residency training, I read Dr. MacWhinney's 24 July 1975, New England Journal of Medicine article, 'Family Medicine in Perspective'. ${ }^{1}$ Family medicine was described as a philosophy, not just another medical specialty. Two quotes define this philosophy:

- 'Family medicine is part of the process by which medicine adjusts itself to the changing needs of society'.

- 'To restore the primacy of the person, one needs a medicine that puts the person in all his wholeness in the centre of the stage and does not separate the disease from the man, and the man from his environment'. 
This article, as well as experiences at medical school, led me to choose family medicine as a career.

After completing a family medicine residency programme in 1979 , I was assigned for 2 years as Division Surgeon (chief medical officer) for a 12,000-soldier infantry unit at Fort Stewart, Georgia. My job was to train and supervise a primary care-based field medical system consisting of physician assistants and medics. Medical specialists from the post hospital would join in field exercises. As I experienced in Vietnam, these physician assistants and medics were extremely effective out in the field where infantry units were widely dispersed.

From 1981 to 1985, I was chief of a 21-resident family medicine programme at Fort Bragg, North Carolina. An affiliation with the Department of Family Medicine at the University of North Carolina (UNC) School of Medicine was very helpful, especially with developing the programme faculty. An important part of the curriculum was leadership training. The graduated residents were expected to supervise medical units in addition to providing medical care. In subsequent years, these family physicians were assigned to many overseas locations including The Sinai, Grenada, Honduras, Kuwait, Iraq and numerous locations in Europe. The rigorous clinical and leadership training also proved to be valuable as they later left the military and either entered private practice, group practice or academic medicine.

The US Army had more than 550,000 soldiers and family members in the 1980s assigned to small posts in The Netherlands, Belgium, Germany, Italy and Turkey. From 1985 to 1988, I was assigned to the headquarters of the army medical command in Heidelberg, Germany, responsible for providing healthcare care for this widely dispersed population. The medical system consisted of 61 community-based clinics supported by 11 army hospitals. Most of the clinics were led by family physicians recently graduated from an army residency programme stressing leadership development. Each of these physician leaders supervised a team of physician assistants, nurses, medics, technicians and administrators. They met regularly with local military commanders to insure all medical needs were met. They also coordinated with nearby host nation hospitals for appropriate back-up when a sick or injured patient could not be evacuated to an army hospital. It was quite impressive to watch these young physician leaders develop and excel in very demanding positions. They would periodically meet and share best practices. They taught each other, and their ideas were used to better train those who would follow them.

From 1989 to 2015, I was a full partner in a 10-clinician, privately owned family practice in Fayetteville, North Carolina. The practice was a medical home for more than 20,000 patients, a place of employment for more than 60 employees, a source of $\$ 4$ million yearly for the local economy and a teaching site for dozens of medical and physician assistant students. In addition to clinic appointments, the practice provided on-site services that included $\mathrm{X}$-rays, lab work, bone density tests, ultrasonography, treadmill stress testing, an extended care clinic open 7 days a week and regular patient education classes. The clinicians also followed nursing home patients and, until 2012, followed all hospitalised patients (including intensive care unit patients). Students from nearby medical and physician assistant schools regularly rotated through the practice. All my partners were deeply involved in community activities and were an important part of the fabric of the community. Most notably, we helped establish and run The CARE Clinic, a local indigent care clinic that has been operating since 1993. The CARE Clinic has managed more than 100,000 medical and dental visits without any financial support from the government or insurance companies.

I was privileged to work outside the practice with several other community physicians as members of the board of directors for the local county medical society. In coordination with the North Carolina Medical Society, we were able to achieve tort reform in 2011. This effort necessitated countless letters, visits and phone calls to local leaders explaining the negative impact caused by North Carolina not having any limits on malpractice awards. The county medical society formed a political action committee and sponsored many debates for those running for the North Carolina General Assembly, Court of Appeals and Supreme Court. We also worked with the UNC School of Medicine to develop a plan to provide appropriate oversight of their faculty serving as expert witnesses in legal matters. These steps produced profound results and provided much needed relief for the patients as well as physicians.

I am now working at a rural family medicine clinic owned and operated by the UVA Health System. Medical students and family medicine residents regularly rotate through the clinic and see an aspect of medicine quite different from what is experienced at the main hospital.

My story is very similar to that of many colleagues who chose the specialty of family medicine in the 1970s. We were inspired by a new way of providing healthcare. Those family medicine founders providing the inspiration are mentioned in 'The Distinguished Dozen: Twelve Books That Shaped the Face of Family Medicine'. ${ }^{2}$ I have spoken with many family physicians of my generation all over the country who want, as I do, to show new family physicians that they are joining a profession with a rich and proud heritage. In an era of government regulation and corporate intervention, there continues to be a need for community-based family physicians willing to step out of their comfort zones and use their clinics as laboratories for innovation.

Funding The authors have not declared a specific grant for this research from any funding agency in the public, commercial or not-for-profit sectors.

Competing interests None declared.

Patient consent for publication Obtained.

Provenance and peer review Not commissioned; internally peer reviewed.

Open access This is an open access article distributed in accordance with the Creative Commons Attribution Non Commercial (CC BY-NC 4.0) license, 
which permits others to distribute, remix, adapt, build upon this work non-commercially, and license their derivative works on different terms, provided the original work is properly cited, appropriate credit is given, any changes made indicated, and the use is non-commercial. See: http:// creativecommons.org/licenses/by-nc/4.0

\section{REFERENCES}

1. MacWhinney IR. Family medicine in perspective. N Engl J Med 1975;293:176-81. doi:.

2. American Academy of Family Physicians Foundation. The distinguished dozen: twelve books that shaped the face of family medicine 2016. 